\title{
sciendo
}

\author{
PAWEŁ KUDŁA, JANUSZ TARCZYDŁO, KACPER KUŚMIREK
}

\section{Dental care in opinion of senior patients from Lublin}

\begin{abstract}
Introduction. The issues of dental office accessibility, professionalism of the service as well as treatment reimbursement often determine geriatric patients' decision regarding treatment. In the era of an aging society, struggling with the intensification of disease processes of the entire system, the belief of the elderly about the value and availability of dental treatments is the key to the wide use of the achievements of modern dental medicine. Thanks to this, there is a chance to improve oral health, which will directly improve the overall health condition of this age group.

Aim. The aim of the study was to know the opinions of senior patients about the quality and availability of dental care for this age group.

Materials and methods. The study was conducted during the Lublin Seniors Meeting LUB-SENIOR 2019 among 100 randomly selected people of both sexes aged 60-75 living in Lublin, who are not residents of retirement homes. An anonymous direct questionnaire with 7 questions regarding dental care was used.

Results. After analyzing the answers given by the respondents $(n=100)$, it was found that $84 \%$ of them showed satisfaction with the dental care available to them. Among the surveyed seniors, $81 \%$ declared having their own dentist, while $25 \%$ expressed the willingness to change him. As much as $80 \%$ of the respondents declared that dentists pay attention to seniors dental health problems. A friendly approach of the dental team to a senior patient was declared by $61 \%$ of the respondents. Preferences concerning the use of dental treatment in private offices were reported by $44 \%$ of thepeople, and within the procedures provided by the NHF - by $45 \%$.

Conclusions. The surveyed senior patients show attachment to their dentist, while expressing a positive opinion on dental care and the treatment. Few people in the studied age group show the willingness to change dentists, which is directly influenced by the doctors' interest in health problems of the elderly.
\end{abstract}

Keywords: geriatric dentistry, dental care, seniors.

DOI: $10.2478 /$ pjph-2021-0008

\section{INTRODUCTION}

In Poland and in other industrialized and developing countries, the increasing life expectancy and declining birth rates indicate aging of the society. The demographic condition in Poland shows that the situation is constantly changing $[1,2]$.

Aging of the population is the cause of many economic, sociological, psychological and health problems. Old age has now become synonymous with the declining period of an individual's life. Meanwhile, old age is a genetically determined stage of normal life, defined in the scientific literature as late adulthood, advanced age, and senior age. There are different classifications of old age, and the biological age often does not coincide with the registered one. It is perceived as a period of a deepening deficit of vitality, and in the social consciousness of most people, there is a negative stereotype of an elderly person [3].

The oral health in people over 60 in Poland is unsatisfactory, and it constantly deteriorates with age [4]. This problem and the malfunction of the stomatognathic system translate into a lower quality of life. Almost half of the people over 74 years old no longer have their natural teeth and $97 \%$ of them suffer from periodontal diseases [4]. The results of oral health studies among the elderly place Poland in one of the last places in Europe. According to the research by Knychalska-Karwan, the dental needs of seniors living in nursing homes and living in family environments are large and relate to restorative, prosthetic and periodontal treatment [1,5]. These problems often make seniors feel marginalized in social life. Malnutrition, pain, and mainly problems related to functionality and aesthetics appear [6]. Human oral health and general health are closely related. The condition of the teeth, oral mucosa, periodontium, and proper chewing of food affect the functions of the body, itsindividual systems as well as mental health and the functioning of the brain. There is scientific evidence linking periodontitis with Alzheimer's disease [7]. The relationship of periodontal diseases with general diseases, including diabetes, chronic kidney disease and cardiovascular diseases, has also 
been proven [8]. The poor condition of the teeth and oral cavity are conducive to the development of sarcopenia, a disease associated with aging, manifested by impairment of the functioning of the muscular system.

Currently, seniors facing negative statistics have become more aware of their needs to improve the functioning of the stomatognathic system, and show greater willingness to learn the principles of proper dental prophylaxis and oral hygiene $[1,5,9]$. However, not all patients are satisfied with the dental treatment [10]. Many elderly patients require careful and special care, some do not want treatment, others do not tolerate waiting for a doctor's appointment. Seniors are highly sensitive, and an interview is often supplemented with long stories about the history of the disease [9]. An elderly person may be a demanding patient in a dental office and may show an attitude that makes it difficult to commence and carry out treatment [11]. The dentist should be empathetic, understanding, resourceful and patient. Each dental treatment plan must be thoroughly explained to the patient and its course clearly explained [1]. The growing number of oral health problems directly implies an increase in the demand for dental services among the elderly.

\section{AIM}

The aim of the paper was to examine the opinions of senior patients on the quality and availability of dental care for this age group.

\section{MATERIAL AND METHODS}

The study was conducted during the Lublin Seniors Meeting LUBSENIOR 2019 among 100 randomly selected people of both sexes aged 60-75 living in Lublin, in family environments. An anonymous direct questionnaire with 7 questions on dental care was used:

- Do you have your dentist?

- Are you satisfied with your dental care?

- Do you use only dental offices offering treatment under the National Health Fund?

- Do you use only private dental offices?

- Do you think you dentist is paying attention to the oral health problems of the seniors?

- Do you think that there are senior-friendly dental offices?

- Do you want to change your dentist? If so, for what reasons:

1. the office is too far away;

2. the dental services are too expensive;

3. the dentist is paying little attention to the patient;

4. the dentist spend little time on talking and treatment;

5. the dentist has no experience in treatment of senior patients disease;

6. the patient is not informed about the treatment opinions, treats and oral cavity diseases of the elderly age.

\section{RESULTS}

After analysing the answers given by the respondents $(n=100)$, it was found that $81 \%$ of them declared having their own dentist, while $19 \%$ of the respondents gave a negative answer (Fig. 1). Among the surveyed seniors, $84 \%$ were satisfied with the dental care they received, and $16 \%$ answered this question in a negative way (Fig. 2). The use of treatment procedures in private clinics was reported by $44 \%$ of people (Fig. 3), and $45 \%$ (Fig. 4) within the NHF. As much as $80 \%$ of the respondents declared that dentists paid attention to the dental health problems of seniors (Fig. 5), and 61\% declared a friendly approach of the dental team to the patient (Fig. 6). The vast majority, i.e. $75 \%$ of the respondents, did not want to change their doctor, but $25 \%$ of all the respondents expressed their willingness to do so (Fig. 7).

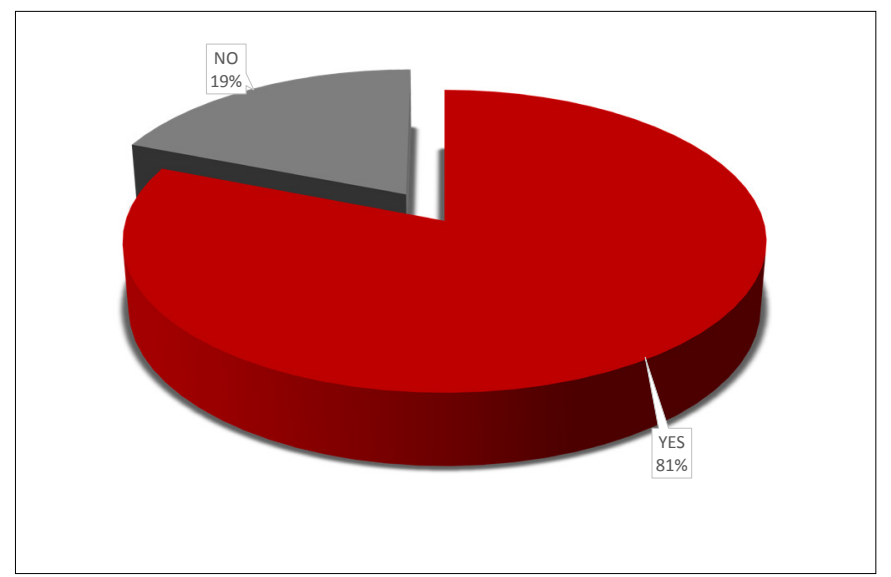

FIGURE 1. Answers to the question about having a dentist.

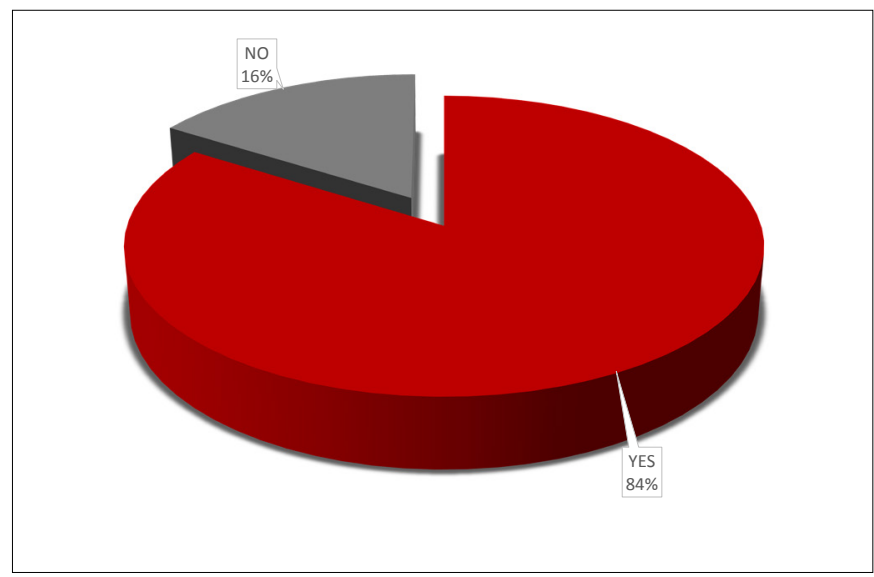

FIGURE 2. Answers to the question about satisfaction with dental care.

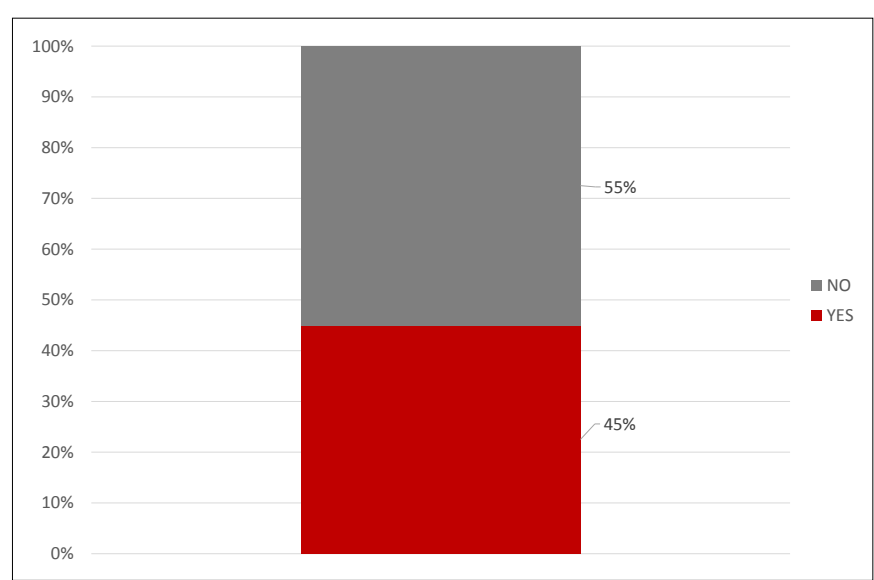

FIGURE 3. Answers to the question about using only dental offices offering treatment under the National Health Fund. 


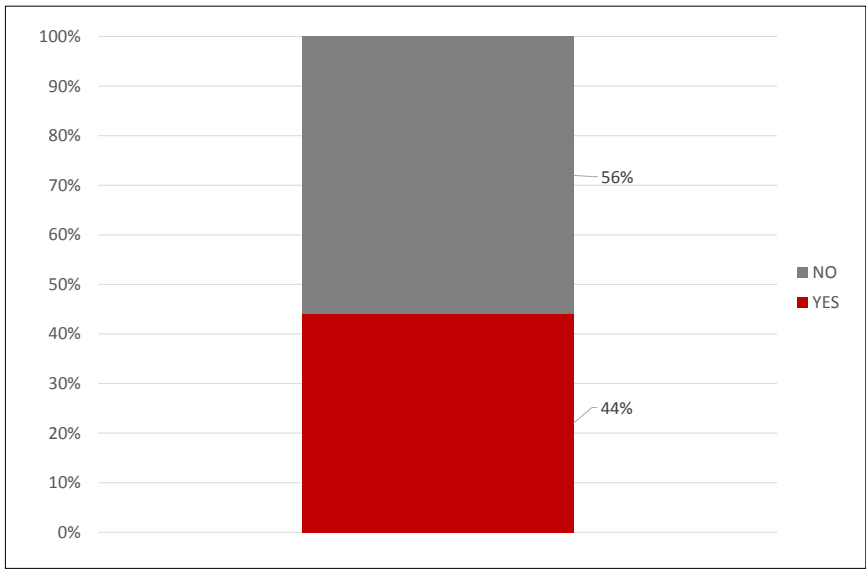

FIGURE 4. Answers to the question about using only private dental offices.

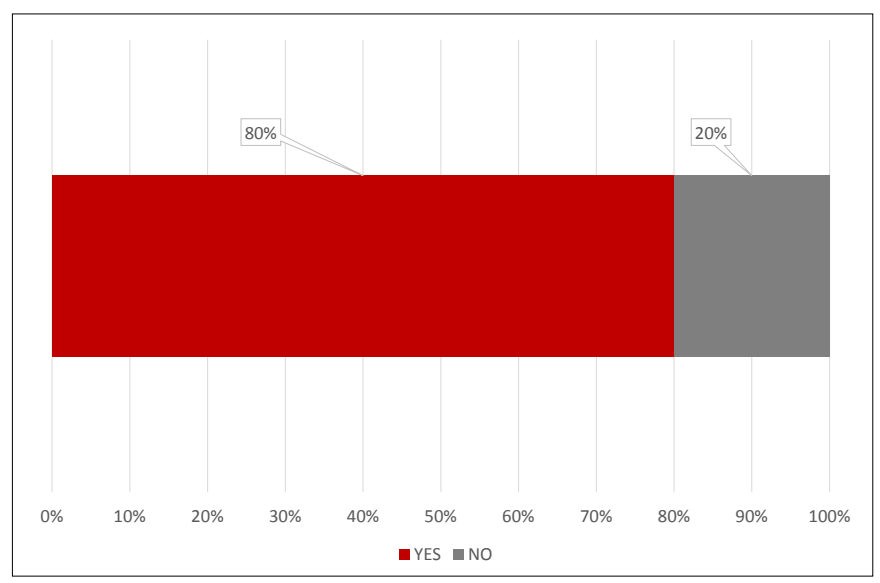

FIGURE 5. Answers to the question regarding opinions on dentists paying attention to the oral health problems of the seniors.

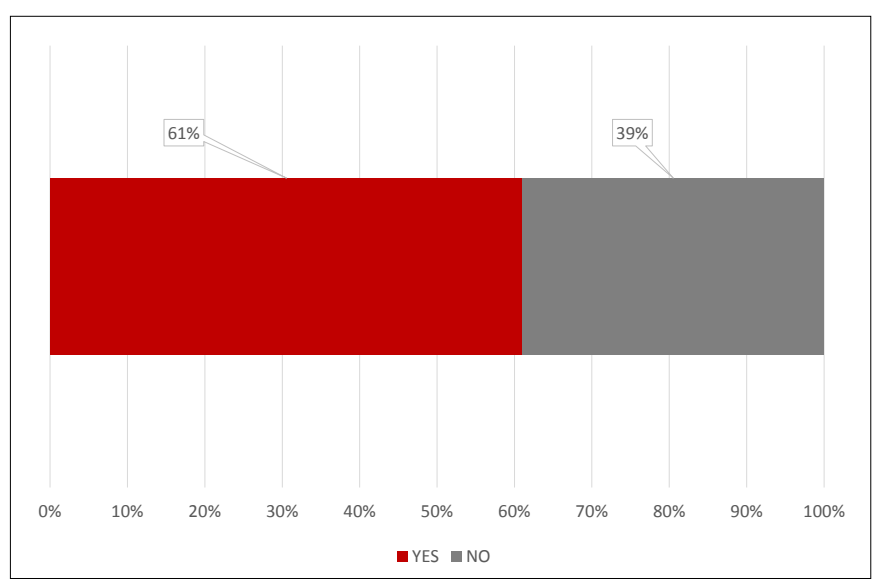

FIGURE 6. Answers to the question regarding opinions on existence of senior-friendly dental offices.

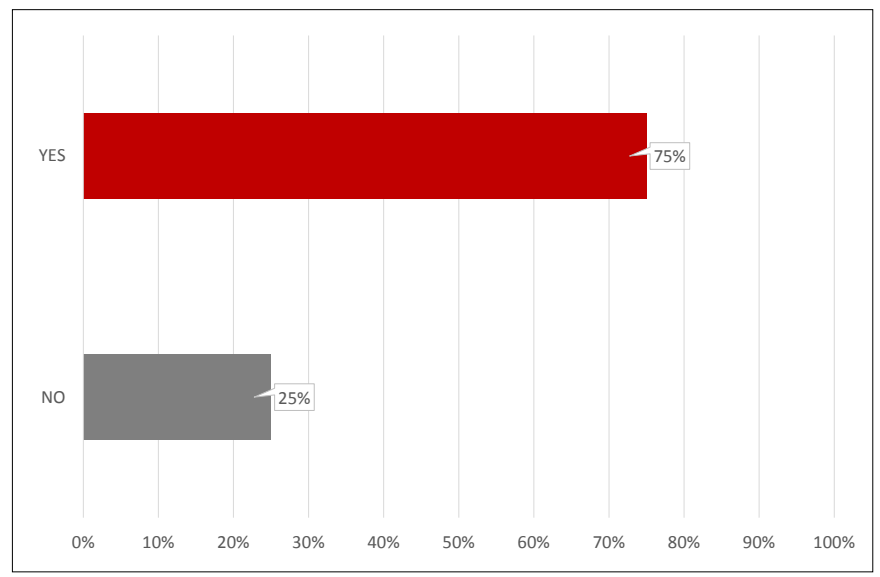

FIGURE 7. Answers to the question about the willingness to change your dentist.

\section{DISCUSSION OF RESULTS}

The structure of the Polish population is constantly changing. According to the Central Statistical Office, by 2050 the percentage of the population aged 65 and over will have increased approximately twice [2].

The health attitudes of elderly people are varied and determined by many factors, including the living environment (i.e. whether they stay in their home, family or nursing homes), as well as physical and mental fitness. Dental treatment for seniors reimbursed under the National Health Fund covers services in the field of conservative dentistry, dental prosthetics, oral surgery, periodontics and emergency care, while only some selected dental procedures are reimbursed, which is often insufficient to fully and at a good level carry out treatment and rehabilitation of the stomatognathic system of elderly people.

Some dental offices undertake preventive actions for the elderly, consisting in free dental check-ups, advice on prosthetic treatment and oral and denture hygiene instruction. The population of senior patients already constitutes a significant group of patients in dental offices. Increased awareness and motivation in addition to the development of widely understood dentistry make their expectations go beyond reimbursed procedures such as two removable overdenture prosthetic restorations.

In Poland, in 2019, the Polish Society of Geriatric Dentistry was established, whose mission is i.a. to provide dental care for the elderly as well as to educate senior patients and medical staff.

Gerodentistry as a subject is already taught at national medical universities as a subject in standard curriculum for medical dentistry. Many European countries, in order to meet the problems of an aging population, modify the system of student education, supplementing it with knowledge in the field of gerodentistry. Lectures, seminars and clinical classes additionally conducted in nursing homes for seniors and in hospitals are aimed at preparing dentistry students for the disease prevention and treatment of elderly patients [12].

The results of a survey conducted among seniors on dental care presented in this paper were prepared on the basis of the answers of respondents living in family environments, showing good psychophysical fitness. The possibility of choosing a dental office and a dentist may have contributed to the positive results of the assessment. The evaluation of dental care in care and treatment institutions (retirement homes) is varied. According to the Report of the Patient Ombudsman from 2021, geriatric patients who lived in pensions show a great demand for dental care, both in terms of treatment and prophylaxis. Only a few institutions conduct a medical interview when admitting patients, and dental check-ups are performed sporadically. In the vast majority of care centres, dental consultations are performed only interventionally, mainly because of pain [13].

According to the study by Wereda and Jończyk, the competences of dental office employees were assessed highly by $84.4 \%$ of respondents, which correlates with the result obtained in the present study (84\%). When it comes to $76.6 \%$ of the respondents in the above study, they expressed satisfaction with the interest shown by the dentist, which corresponds to $80 \%$ obtained in the present study in the $60-75$ age group. As much as $90 \%$ of the respondents in the aforementioned study 
positively assessed the approach of the dental team, and in our study a result of $61 \%$ was obtained [14].

The cited results show the clear influence of the non-medical behaviour of the dental staff on the interpretation of the team's competences and the perception of a dentist by a patient [15]. Both the high quality of and the atmosphere during the procedure are of great importance as it creates a real opportunity to gain the patient's trust and sympathy, which has an impact on the overall assessment of dental treatment.

Senior patients willingly use dental services both in private clinics and as part of the National Health Fund. The preferences regarding the choice of the type of services are similar. Wereda and Jończyk prove that $70 \%$ of decisions regarding the choice of a given medical service are factors unrelated to the essence of the treatment, i.e. the so-called "additional benefits" [14].

The treatment of senior patients requires an adequate approach of the physician-dentist as well as appropriate qualifications in the field of gerodentistry, allowing the proper performance of dental procedures. It can be safely stated that seniors are demanding patients. Despite this, the requirements of seniors do not match their needs. Creating awareness in this area is a challenge for contemporary gerodentistry.

\section{CONCLUSIONS}

The studied senior patients from Lublin show attachment to their dentist, expressing a positive opinion on dental care and the course of treatment. The willingness to change the dentist was declared by a small percentage of the studied group, which is directly influenced by the dentist' interest in health problems of the elderly. The preferences of seniors regarding treatment in private clinics or under the National Health Fund are similar, and the assessment of the work of dental teams by seniors was positive.

\section{ACKNOWLEDGEMENTS}

We are very grateful to Dr. Bożena Tarczydło $\mathrm{MD}, \mathrm{PhD}$ for her support and valuable advice during the implementation of this research project.

\section{REFERENCES}

1. Knychalska-Karwan Z. Pacjent geriatryczny w gabinecie stomatologicznym. Mag Stomatol. 2004:14(7-8):11-4.

2. Prognoza ludność na lata 2014-2050. Główny Urząd Statystyczny. 2014. [https://stat.gov.pl/download/gfx/portalinformacyjny/pl/defaultaktualnosci/5469/1/5/1/prognoza_ludnosci_na_lata_2014___2050.pdf]

3. Black SA, Rush RD. Cognitive and functional decline in adults aged 75 and older. J Am Geriatr Soc. 2002;50(12):1978-86.

4. Wysokińska-Miszczuk J, Sieczkarek J. Gerostomatologia - uzasadnienia teoretyczne i przy-datność praktyczna w naukach medycznych. Twój Prz Stomatol. 2002;1(2):26-7.

5. Knychalska-Karwan Z. Zagadnienia stomatologii geriatrycznej. Mag Stom. 2000;10(12):10-2.

6. Barczak K, Szmidt M, Buczkowska-Radlińska J. Funkcjonalność narządu żucia a poczucie depresji u pacjentów po 55 roku życia zamieszkałych w środowisku rodzinnym i w domach pomocy społecznej. Psychiatr Pol. 2016;50(5):1027-38.

7. Chen CK, Wu YT, Chang YC. Association between chronic periodontitis and the risk of Alzheimer's disease: a retrospective, population-based, matched-cohort study. Alzheimers Res Ther. 2017;9(1):1-7.

8. Wojtkowska AA, Wysokiński A. Wpływ zapalenia przyzębia na występowanie chorób układu sercowo-naczyniowego. Choroby Serca i Naczyń. 2015;12(5):289-94.

9. Barczak K, Buczkowska-Radlińska J, Witek A. Stan zębów i potrzeby lecznicze seniorów z ośrodków pomocy społecznej i domów rodzinnych w województwie zachodniopomorskim. Mag Stomatol. 2012;22(1):114-8.

10. Kaczorowski B, Gawriołek M, Siniawska J. Porównawcza ocena stomatologicznych po-trzeb pensjonariuszy Domów Opieki Społecznej z Poznania i terenu Wielkopolski. Dent Fo-rum. 2008;36(1):27-33.

11. Bagińska J, Chałas R, Rusyan E, Mielczarek A. Profilaktyka stomatologiczna - zalecenia dla osób starszych, rezydentów domów opieki i ich opiekunów. Stanowisko grupy roboczej Polskiego Oddziału Sojuszu dla Przyszłości Wolnej od Próchnicy (ACFF) ds. zapobiegania próchnicy w populacji osób dorosłych. Nowa Stomatol. 2020;3:82-92.

12. Preshaw PM, Mohammad AR. Geriatric dentistry education in European dental schools. Eur J Dental Educ. 2005;9(2):73-7.

13. Sytuacja zdrowotna pacjentów przebywających w zakładach opiekuńczoleczniczych, w zakresie opieki stomatologicznej. Rzecznik Praw Pacjenta; 2021. [https://www.gov.pl/web/rpp/sytuacja-zdrowotna-pacjentow-przebywajacych-w-zakladach-opiekunczo-leczniczych-w-zakresie-opiekistomatologicznej]

14. Wereda W, Jonczyk JA. The role of customer satisfaction in the modern marketing on the example of the market of dental services. Zeszyty Naukowe SGGW w Warszawie. Polityki Europejskie, Finanse i Marketing. 2016;16(65):114-27.

15. Kirenko J, Sienkiewicz E, Szymańska J, Malm A. Socjodemograficzne uwarunkowania sposobów radzenia sobie w sytuacjach trudnych przez personel pielęgniarski. Lubelski Roczn Pedagog. 2019;37(3):93-106.

\section{Corresponding author}

Paweł Kudła

Student Research Circle at Chair and Department of Conservative Dentistry with Endodontics, Medical University of Lublin

6 Chodźki St., 20-950 Lublin

E-mail: pawel.kudla@outlook.com 